\title{
Species-specific effects of fluid shear on grazing by sea urchin larvae: comparison of experimental results with encounter-model predictions
}

\author{
Elisa M. Maldonado, Michael I. Latz* \\ Scripps Institution of Oceanography, University of California, San Diego, La Jolla, California, USA
}

\begin{abstract}
Small-scale turbulence can alter the rate of plankton predator-prey encounters. Encounter models predict that prey ingestion by slow-swimming zooplankton is enhanced at low levels of turbulence. We investigated whether small-scale turbulence increases ingestion for the slow-swimming, suspension-feeding pluteus larvae of the white urchin Lytechinus pictus and the purple urchin Strongylocentrotus purpuratus. Model predictions of the critical level of turbulence, $\varepsilon_{\mathrm{cr}}$, above which encounters due to turbulence are greater than those due to behavior (swimming or suspension feeding) alone, were experimentally tested using short- and long-term grazing treatments. Because urchin larvae are smaller than the smallest eddy scales of turbulence and thus experience turbulence as laminar shear, larvae were exposed to flow conditions using a simple laminar shear flow with dissipation rates, $\varepsilon$, of $0,0.1,0.4$, and $1 \mathrm{~cm}^{2} \mathrm{~s}^{-3}$. Short-term ingestion of beads by $L$. pictus larvae was unaffected by $\varepsilon<1 \mathrm{~cm}^{2} \mathrm{~s}^{-3}$ but was $30 \%$ greater at this level, which was greater than $\varepsilon_{\mathrm{cr}}$ based on flow speeds produced in suspension feeding. Long-term flow treatments with algal prey had no significant effect on grazing or growth. Short-term ingestion of beads by $S$. purpuratus larvae was unaffected by $\varepsilon<\varepsilon_{\mathrm{cr}}$ based on suspension feeding; the effect of long-term flow exposure on ingestion and growth could not be investigated because of high mortality, suggesting greater sensitivity to flow exposure compared to L. pictus. Experimental results are consistent with model predictions that $\varepsilon_{\mathrm{cr}}$ is high, and thus levels of turbulence in the ocean are not expected to significantly increase ingestion and reduce food limitation in suspension-feeding urchin larvae.
\end{abstract}

KEY WORDS: Grazing $\cdot$ Larvae $\cdot$ Turbulence $\cdot$ Urchin $\cdot$ Encounter model

\section{INTRODUCTION}

The encounters between plankton predators and prey are influenced by small-scale turbulence (Rothschild \& Osborn 1988) due in part to the velocity difference between predator and prey (Denman \& Powell 1984, Tett \& Edwards 1984, Rothschild 1986). Turbulence increases this velocity difference, resulting in encounter rates that increase with turbulence level (Kiørboe \& Saiz 1995, Shimeta et al. 1995, Kiørboe 1997).

The effect of turbulence on predator-prey encounters is species specific (Shimeta et al. 1995). The critical turbulence level, $\varepsilon_{\mathrm{cr}}$, determines whether encoun- ters are dominated by turbulence or behavior. Below $\varepsilon_{\mathrm{cr}}$, encounter rates are primarily determined by the feeding behavior and swimming or feeding current speed of the predator (Kiørboe \& Saiz 1995, Shimeta et al. 1995, Kiørboe 1997). Above $\varepsilon_{\mathrm{cr}}$, fluid motion dominates over behavioral processes. For some nonmotile and slow-swimming organisms, such as the slowest-swimming flagellates and ciliates (swimming speed $\sim 20 \mu \mathrm{m} \mathrm{s}^{-1}$ ), $\varepsilon_{\mathrm{cr}}$ is low and turbulence is important because the velocity difference between predator and prey is small relative to turbulence (Saiz \& Kiørboe 1995, Shimeta et al. 1995). Experimental results are also consistent with predator-prey encounter theory that turbulence has no significant ef- 
fect on contact rates for fast-moving or suspensionfeeding predators, such as copepods and fish larvae, because the velocity difference between predator and prey is large relative to turbulent velocity fluctuations and $\varepsilon_{\mathrm{cr}}$ is very high (Rothschild \& Osborn 1988, Kiørboe \& Saiz 1995, Saiz \& Kiørboe 1995).

Prey ingestion typically exhibits a dome-shaped response as turbulence intensity increases (Holling 1961, MacKenzie et al. 1994, Kiørboe \& Saiz 1995). The rising phase of the response is due to enhanced encounters resulting in increased ingestion up to a maximum level. Higher turbulence levels can result in decreased ingestion despite predicted increases in encounter rates. Turbulence levels greater than those resulting in maximum ingestion can negatively affect feeding by eroding the hydromechanical signal of a prey detected by the predator or change prey or predator behavior (Alcaraz et al. 1994, MacKenzie et al. 1994, Kiørboe \& Saiz 1995). Ingestion can also decrease when the local velocity imposed by turbulence is greater than the feeding current speed or reaction time of the predator (MacKenzie et al. 1994, Kiørboe \& Saiz 1995, MacKenzie \& Kiørboe 1995, 2000, Shimeta et al. 1995).

This study focused on sea urchin larvae, representative of the slow-swimming planktotrophic larvae of benthic marine invertebrates for which the effects of turbulence on encounters and ingestion are unknown. Small-scale turbulence could affect food availability; if larvae are food limited in the ocean (Paulay et al. 1985), then changes in food availability will affect larval survival, larval development time (Meyer et al. 2007), and post-metamorphic juvenile survival (Jarrett 2003, Pineda et al. 2007), all of which are important for recruitment success, reproductive population connectivity, and fisheries management. Additionally, it is important to understand grazing in larvae because they feed on phytoplankton and protists and are grazed upon by other zooplankton, especially copepods and fish larvae, providing an important component of the planktonic food web (Hansen et al. 1994). Finally, larvae can also contribute to biogeochemical cycles by converting phytoplankton into carbon for metabolic energy or export to deep water as biomass or detritus (Sterner et al. 1992, Cloern 1996). Thus, an understanding of larval grazing is important to modeling the ocean carbon cycle (Six \& Maier-Raimer 1996).

One formulation (Kiørboe \& Saiz 1995) of predatorprey encounter theory was used to calculate a critical turbulence level, $\varepsilon_{\mathrm{cr}}$, for urchin larvae. $\varepsilon_{\mathrm{cr}}$ determines whether encounters are dominated by behavior or turbulence, and is dependent on predator swimming or feeding current speed and perceptive radius (Kiørboe \& Saiz 1995). Although urchin larvae use ciliary currents to swim and have relatively lower swimming speeds compared to other zooplankton such as copepods and fish larvae, they are also suspension feeders that can sense and capture individual particles (Strathmann 2007). Additionally, urchin larvae first detect particles at the tips of their $20 \mu \mathrm{m}$ long cilia and then move the particles towards their mouth using reversal of ciliary beat (Strathmann 1971, 2007). Thus, because the local velocity at the tips of the cilia is low, larvae can react to the prey and turbulence may not decrease ingestion.

A unique experimental approach was used to test these predictions. At the small scale of larvae, viscosity dominates and turbulence is experienced as laminar shear (i.e. fluid rate of strain; Lazier \& Mann 1989). Thus, the effects of small-scale turbulence on ingestion in urchin larvae were studied using a laminar shear-generating laboratory apparatus not previously used with marine invertebrate larvae. This approach is powerful because the flow field is fully characterized and the shear level can be quantified to determine the exact levels of shear that are important for grazing in sea urchin larvae.

\section{MATERIALS AND METHODS}

\section{Test organisms}

Adults of the purple urchin Strongylocentrotus purpuratus (Stimpson 1857) and white urchin Lytechinus pictus (Verrill 1867) were held at ambient temperature in flow-through aquaria at the Experimental Aquarium Facility at the Scripps Institution of Oceanography. Adults were injected with $0.5 \mathrm{M} \mathrm{KCl}$ to induce spawning. For each experiment, the eggs from 1 female were then fertilized with the sperm of 1 male. Two days after fertilization, prism-stage larvae were transferred to 31 glass jars filled with $0.45 \mu \mathrm{m}$ filtered seawater (FSW) at a temperature of $20^{\circ} \mathrm{C}$ for L. pictus and $16^{\circ} \mathrm{C}$ for $S$. purpuratus, to achieve a concentration of 2 larvae $\mathrm{ml}^{-1}$ unless stated otherwise. The antibiotic penicillin was added to the cultures at a concentration of $50 \mathrm{mg} \mathrm{ml}^{-1}$ to prevent bacterial growth. Larvae were fed the alga Rhodomonas lens (Pascher 1913) at an initial concentration of 300 cells $\mathrm{ml}^{-1}$. This prey species was chosen for its high nutritional value to urchin larvae (Strathmann 1975, Schiopu et al. 2006). Experiments were conducted $3 \mathrm{~d}$ after fertilization, when pluteus larvae were at the early 4 -armed stage of development in $L$. pictus and late prism stage in 
A) Lytechinus pictus

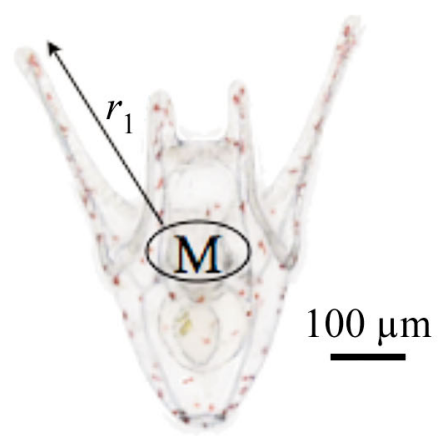

B) Strongylocentrotus purpuratus
C) Copepod

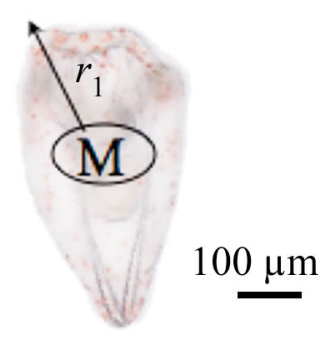

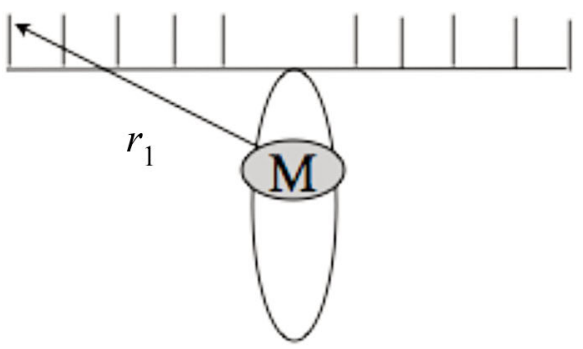

Fig. 1. Parameters included in the encounter model for urchin larvae are similar to those for copepod-based models. The perceptive radius $\left(r_{1}\right)$ is the distance from the mouth (M) over which particles can be sensed. (A) Lytechinus pictus 4-armed stage larva. (B) Strongylocentrotus purpuratus late prism stage larva. (C) Schematic representation of a copepod, modified from Kiørboe \& Saiz (1995)

S. purpuratus. These are critical stages of development when larvae become fully competent to feed; food-limited larvae during this time have a lower likelihood of recovering and surviving to metamorphosis (Fenaux et al. 1988, Kelly et al. 2000).

\section{Parameters for the encounter model}

The predator-prey encounter model proposed by Kiørboe \& Saiz (1995) states that the encounter rate, $E$, per predator is based on the behavioral encounter kernel, $\beta_{\mathrm{beh}}$, the encounter kernel due to turbulence, $\beta_{\text {turb, }}$ and the concentration of prey, $C_{\text {prey }}$ :

$$
E=\left(\beta_{\text {beh }}+\beta_{\text {turb }}\right) C_{\text {prey }}
$$

$\beta_{\text {beh }}$ and $\beta_{\text {turb }}$ quantify the different behavioral and physical processes that can cause a velocity difference between predator and prey to result in an encounter. They are dependent on the perceptive radius of the predator, $r_{1}$, radius of the prey, $r_{2}$, and the swimming velocity or the speed of the feeding current generated by a suspension-feeding predator, $u_{1}$, so that:

$$
E=\left[\pi\left(r_{1}+r_{2}\right)^{2} u_{1}+4.2 \pi \varepsilon^{0.5}\left(r_{1}+r_{2}\right)^{2}\right] C_{\text {prey }}
$$

where $\varepsilon$ is the turbulence level expressed as the dissipation rate of kinetic energy $\left(\mathrm{cm}^{2} \mathrm{~s}^{-3}\right)$. When $\beta_{\text {turb }}>$ $\beta_{\mathrm{beh}}$, turbulence is predicted to dominate prey encounters. This is used to calculate a critical turbulence level, $\varepsilon_{\mathrm{cr}}$, above which encounters due to turbulence are greater than those due to behavior alone (Kiørboe \& Saiz 1995):

$$
\varepsilon_{\mathrm{cr}}=0.057\left(u_{1}^{2} / r_{1}^{2}\right)
$$

In this study, we tested model predictions incorporating both swimming speed and feeding current.

The first parameter for the encounter model, perceptive radius, the distance at which particles are sensed, is based on the length of the urchin larval arms (Fig. 1A,B), because particles are sensed at the tips of cilia that run in bands along the larval arms and moved towards the mouth using a local reversal of ciliary beat (Strathmann 2007). A perceptive radius of $0.28 \mathrm{~mm}$ for Lytechinus pictus larvae and $0.18 \mathrm{~mm}$ for Strongylocentrotus purpuratus larvae was used (Table 1). For modeling purposes, the larval arms are equivalent to the antennules in copepods, the lengths of which are used as the perceptive radius (Fig. 1C).

The second parameter for the behavioral encounter kernel is speed, $u_{1}$, of the prey particle relative to the urchin larvae. Urchin larvae swim using bands of cilia arranged along the larval arms. Larval swimming speeds were determined experimentally; $u_{1}$ was $0.4 \mathrm{~mm} \mathrm{~s}^{-1}$ for Lytechinus pictus and $0.2 \mathrm{~mm} \mathrm{~s}^{-1}$ for Strongylocentrotus purpuratus (Maldonado 2009). Calculations based on swimming speed indicated that $\varepsilon_{\mathrm{cr}}=0.11 \mathrm{~cm}^{2} \mathrm{~s}^{-3}$ for L. pictus larvae and $\varepsilon_{\mathrm{cr}}$ $=0.07 \mathrm{~cm}^{2} \mathrm{~s}^{-3}$ for $S$. purpuratus larvae (Table 1).

Table 1. Lytechinus pictus and Strongylocentrotus purpuratus. Estimates of

\begin{tabular}{|c|c|c|c|c|c|}
\hline & \multirow[t]{2}{*}{$r_{1}(\mathrm{~cm})$} & \multicolumn{2}{|c|}{$-u_{1}\left(\mathrm{~cm} \mathrm{~s}^{-1}\right)-$} & \multicolumn{2}{|c|}{$-\varepsilon_{\mathrm{cr}}\left(\mathrm{cm}^{2} \mathrm{~s}^{-3}\right)$} \\
\hline & & Swimming & $\begin{array}{c}\text { Feeding } \\
\text { current }\end{array}$ & Swimming & $\begin{array}{c}\text { Feeding } \\
\text { current }\end{array}$ \\
\hline L. pictus & 0.028 & 0.04 & 0.1 & 0.11 & 0.7 \\
\hline S. purpuratus & 0.018 & 0.02 & 0.1 & 0.07 & 1.7 \\
\hline
\end{tabular}
critical turbulence level, $\varepsilon_{\mathrm{cr}}$, based on perceptive radius, $r_{1}$, and swimming or feeding current speed, $u_{1}$ 
Urchin larvae are also suspension feeders that use a feeding current with sensing and capture of individual particles (Strathmann 2007). In this case, $u_{1}$ is the velocity of the prey in the feeding current as it enters the perceptive radius (Kiørboe \& Saiz 1995). Feeding current speeds are $0.98 \mathrm{~mm} \mathrm{~s}^{-1}$ for 4 -armed Strongylocentrotus purpuratus larvae (Hart 1996). Although feeding current speeds are not available for Lytechinus pictus larvae, feeding current speed does not depend on ciliary band length (Hart 1996). For example, the feeding current speed of $1.16 \mathrm{~mm}$ $\mathrm{s}^{-1}$ for Dendraster excentricus pluteus larvae is similar to that of $S$. purpuratus larvae, even though they have longer ciliary bands (Hart 1996). Thus, an average feeding current speed of $1 \mathrm{~mm} \mathrm{~s}^{-1}$ was used for both $S$. purpuratus and L. pictus larvae. Calculations based on feeding current indicated that $\varepsilon_{\mathrm{cr}}=0.7 \mathrm{~cm}^{2}$ $\mathrm{s}^{-3}$ for L. pictus larvae and $\varepsilon_{\mathrm{cr}}=1.7 \mathrm{~cm}^{2} \mathrm{~s}^{-3}$ for $S$. purpuratus larvae (Table 1).

The lowest values represent levels present near the surface of the ocean on a stormy day, while the highest levels are much higher than what occurs in the coastal zone of the ocean (Soloviev et al. 1988, Gargett 1989, Thomas \& Gibson 1990, Granata \& Dickey 1991, MacKenzie \& Leggett 1991, Jiménez 1997). Thus, $\varepsilon_{\mathrm{cr}}$ based on feeding current is higher than turbulence generally experienced by urchin larvae, and leads to the prediction that ocean turbulence will not increase ingestion in urchin larvae.

\section{Flow apparatus}

Larvae were subjected to either still conditions or constant shear using simple Couette flow generated in the gap between concentric cylinders with only the outer cylinder rotating at constant speed. This flow field is characterized by a linear velocity gradient in the seawater-filled gap between the 2 cylinders, resulting in nearly constant shear throughout the chamber volume (Coles 1965). Thus, larvae within the gap experience a uniform flow environment. Simple Couette flow has been used previously to study the effect of shear on the growth (Thomas \& Gibson 1990, Juhl et al. 2000, Juhl \& Latz 2002), bioluminescence (Latz et al. 1994, Maldonado \& Latz 2007), and suspension feeding (Shimeta et al. 1995) of planktonic protists.

The flow chambers used in this study were the same previously used in growth studies (Juhl et al. 2001, Latz et al. 2009). They were constructed of clear acrylic with the following dimensions: inner radius $\left(r_{\mathrm{i}}\right)=20.5 \mathrm{~mm}$; outer radius $\left(r_{\mathrm{o}}\right)=24 \mathrm{~mm}$; height of fluid $(\mathrm{h})=200 \mathrm{~mm}$; fluid volume in gap = $265 \mathrm{ml}$. The bottom end cap of the outer cylinder was mounted to a pulley system with plastic chain to couple 4 replicate chambers to a Silvermax servomotor (QuickSilver Controls). Motor speed was controlled by custom software on a personal computer (Latz et al. 2009). The mean shear rate, $G$, within the gap is calculated as:

$$
G=\left[\left(2 \omega_{\mathrm{o}} r_{\mathrm{o}} r_{\mathrm{i}}\right) /\left(r_{\mathrm{o}}^{2}-r_{\mathrm{i}}^{2}\right)\right]
$$

where $\omega$ is the angular velocity $(\omega=2 \pi N / 60$, where $N$ is the rotational speed in rpm; Schlichting 1979). The rotation rate of the outer cylinder in all experiments was either $0,1.5,6$, or $15 \mathrm{rpm}$, representing shear rates of 0 (still control), 1 ('low'), 4 ('moderate'), and 10 ('high') $\mathrm{s}^{-1}$, respectively. Dissipation rate, $\varepsilon$, is related to shear as:

$$
\varepsilon=G^{2} V
$$

where $V$ represents the fluid kinematic viscosity $\left(\mathrm{cm}^{2} \mathrm{~s}^{-1}\right)$. Thus, the tested shear levels are equivalent to dissipation rates, $\varepsilon$, of $0,0.1,0.4$, and $1 \mathrm{~cm}^{2} \mathrm{~s}^{-3}$, which represent oceanic conditions in near-surface waters under the influence of moderate to strong winds (Soloviev et al. 1988, Gargett 1989, Thomas \& Gibson 1990, Granata \& Dickey 1991, MacKenzie \& Leggett 1991, Jiménez 1997).

\section{Short-term grazing experiments}

Short-term grazing studies to determine the effect of flow on encounters between urchin larvae and prey were performed with beads rather than algal prey. Urchin larvae have low ingestion rates compared to fish larvae, making it difficult to extrapolate changes in cell concentration over short periods of time using indirect estimates of grazing. Thus, direct estimates of ingestion rates were made by counting prey particles in the larval stomachs. Fluorescent or non-fluorescent beads are commonly used as prey mimics to obtain short-term grazing rates in a wide variety of suspension-feeding planktonic and benthic organisms (Børsheim \& Andersen 1987, Hall et al. 1993, Appelmans 1994, Pedrotti 1995, Hart 1996, Shimeta 2009, Riisgard \& Larsen 2010). In this study, beads were chosen because algal cells disintegrate immediately upon ingestion, so that methods based on the counting of prey cells and measuring chlorophyll fluorescence of the prey are not feasible (Maldonado 2009). Specifically, urchin larvae ingest beads that are 'flavored', or soaked in algal filtrate (Podolsky 1994). Based on initial preference tests, 
Lytechinus pictus larvae were incubated with beads flavored with the green alga Dunaliella tertiolecta (Butcher 1959) CCMP strain 1320, and Strongylocentrotus purpuratus were incubated with beads flavored with the red alga Rhodomonas lens CCMP strain 739. To flavor beads, $1.5 \mathrm{ml}$ of the $D$. tertiolecta or $R$. lens culture in exponential growth phase was added to an Eppendorf tube and centrifuged for $15 \mathrm{~min}$ at $13000 \times g$ to pellet the cells. The supernatant was removed and combined with $1.0 \mathrm{ml}$ of autoclaved FSW that contained a $60 \mu \mathrm{l}$ volume of $20 \mu \mathrm{m}$ polystyrene DVB microspheres (SPI) that had been rinsed twice in autoclaved FSW. The beads were soaked overnight in the algal exudate.

At the beginning of each experiment, 85 larvae were added to $170 \mathrm{ml}$ of FSW in each flow chamber and acclimated in the chambers for $30 \mathrm{~min}$. After this time, each chamber was inoculated with beads to achieve an initial concentration of 300 or $2500 \mathrm{ml}^{-1}$. These 2 concentrations were chosen to determine whether the flow conditions can help larvae overcome food limitation. Larval growth rates are lower and development time is longer, suggesting food limitation, when larvae are raised on 300 cells ml $^{-1}$ compared to 2500 cells ml $^{-1}$ food concentration (Hart \& Strathmann 1994). Larvae were then exposed to a flow condition with $\varepsilon$ values of 0 (still control), 0.1, 0.4 , or $1 \mathrm{~cm}^{2} \mathrm{~s}^{-3}$ for $30 \mathrm{~min}$. Preliminary experiments indicated that greater ingestion was achieved in $30 \mathrm{~min}$ compared to 10 and $20 \mathrm{~min}$. After the $30 \mathrm{~min}$ incubation, larvae were removed from the chambers, fixed in formalin, and observed under a compound microscope to count the number of beads in the stomach and intestine. There were 4 replicate chambers for each shear treatment, and each experiment was performed twice.

Values of ingestion rates (no. beads ingested larva ${ }^{-1} \mathrm{~h}^{-1}$ ) and clearance rates $\left(\mathrm{ml}\right.$ larva $\left.^{-1} \mathrm{~h}^{-1}\right)$, obtained by dividing the ingestion rate by the concentration of beads, were expressed as means $+\mathrm{SD}$, with $\mathrm{n}$ equaling the number of larvae per treatment. Data were log-transformed for statistical testing.

\section{Long-term growth experiments}

Ingestion rates during long-term experiments were determined based on the depletion of prey. To calculate grazing rates using the equations of Frost (1972), the intrinsic growth rate of Rhodomonas lens in the absence of larvae was measured at each turbulence level. Although Lytechinus pictus larvae preferred the taste of Dunaliella tertiolecta, a unialgal diet of this species is insufficient to support larval growth (George et al. 2004). R. lens was chosen because they are sufficient to support larval growth. They are also motile, promoting a homogeneous prey spatial concentration. $R$. lens was added to each chamber at an initial concentration of 300 cells ml $^{-1}$ and grown on a 12:12 h light:dark cycle. After $4 \mathrm{~d}$, a $20 \mathrm{ml}$ sample was removed from each chamber, and cell concentration was measured using an Elzone II particle counter (Micromeritics). There were 4 replicate chambers for each shear treatment, and each experiment was performed twice. The exponential net growth rate $(k)$ was calculated based on the change in prey concentration over $4 \mathrm{~d}$ and expressed as the mean with SD.

To test the effects of flow on ingestion and growth, larvae were incubated with algal cells and exposed to laminar shear flow for $12 \mathrm{~h} \mathrm{~d}^{-1}$ for $8 \mathrm{~d}$ during their night phase. The daily duration of flow exposure simulated diel variability in turbulence due to wind stress or convective mixing. It was also insufficient to cause larval mortality, which occurred for longer flow exposure. Extensive preliminary tests with Lytechinus pictus larvae determined that the time of day of flow exposure had no effect on growth, and that an $8 \mathrm{~d}$ experiment duration avoided significant mortality, which occurred for longer experiment durations. Larvae were added to $250 \mathrm{ml}$ of FSW in each chamber. To optimize the experimental conditions, extensive preliminary experiments tested the effects of larval concentrations of $0.5,1,2$, and $3 \mathrm{ml}^{-1}$ on grazing and survival of larvae after 4 and $8 \mathrm{~d}$. The goal was to use the lowest concentration that caused a measurable decrease in prey concentration while minimizing density-dependent effects on grazing and mortality. Based on these initial tests, optimal larval concentrations that produced consistent grazing and survival rates across shear treatments were 0.5 larvae $\mathrm{ml}^{-1}$ for $L$. pictus and $2 \mathrm{ml}^{-1}$ for Strongylocentrotus purpuratus. Larvae were fed Rhodomonas lens at a food-limiting initial concentration of 300 cells ml$^{-1}$ (Hart \& Strathmann 1994). Higher concentrations were not tested due to density-dependent effects, based on preliminary experiments with concentrations of 2500 cells ml-1 ${ }^{-1}$, which increased mortality by $70 \%$. Preliminary experiments also examined ingestion rates every $24 \mathrm{~h}$, and revealed that a $4 \mathrm{~d}$ period was the shortest that could resolve changes in prey concentrations given low ingestion rates by larvae and low larval concentrations. Every $4 \mathrm{~d}, 20 \mathrm{ml}$ samples were removed from each chamber to determine the concentration of $R$. lens using the particle counter. There were 4 replicate chambers for each flow treatment, and each experiment was performed 
twice. Ingestion rates were calculated using the equations of Frost (1972) for the 4 to $8 \mathrm{~d}$ period.

To determine the effect of flow on growth, postoral (PO) arm length was measured using an ocular micrometer attached to a compound microscope. PO arm length is typically considered in studies on the effects of food limitation on growth of urchin larvae (Strathmann et al. 1992, Hart \& Strathmann 1994). Specifically, early in development, PO arm length relative to body length is greater in starved compared to satiated larvae. After several days, however, satiated larvae develop faster and have larger overall PO arm lengths compared to starved larvae (Strathmann et al. 1992, Hart \& Strathmann 1994). For each experimental condition, measurements from 20 larvae were made to the nearest $10 \mu \mathrm{m}$. PO arm length was expressed as a mean and $\mathrm{SD}$, with $\mathrm{n}$ equaling the number of larvae per treatment.

Finally, the concentration and developmental stage of larvae were also determined for each $20 \mathrm{ml} \mathrm{sam-}$ ple. Developmental stages in Lytechinus pictus and Strongylocentrotus purpuratus were defined as follows: late prism stage = gut fully formed, postoral and antero-lateral arms not fully formed; early 4-armed pluteus $=$ postoral and anterolateral arms fully formed, obvious gut; late 4-armed pluteus = with 'bud' of postdorsal arms; 6-armed pluteus = fully formed PO, anterolateral, and postdorsal arms; and 8-armed pluteus = fully formed preoral arms (Lamare $\&$ Barker 1999, Sewell et al. 2004). The proportions of larvae at each developmental stage were arcsine transformed for statistical analysis.

\section{Statistical analyses}

Unless otherwise stated, data were tested for statistical significance using a 1-way analysis of variance (ANOVA) with Tukey's test used for post hoc paired comparisons. Statistical differences were based on an $\alpha=0.05$ criterion. All statistical analyses were performed using Prism (GraphPad Software).

\section{RESULTS}

\section{Short-term grazing experiments}

Ingestion rates of Lytechinus pictus larvae fed a concentration of 300 beads $\mathrm{ml}^{-1}$, equivalent to a limiting prey concentration, were similar for flow treatments with $\varepsilon<1 \mathrm{~cm}^{2} \mathrm{~s}^{-3}$; the pooled average ingestion rate was $3.7 \pm 2.6$ beads larva ${ }^{-1} \mathrm{~h}^{-1}$ and clearance

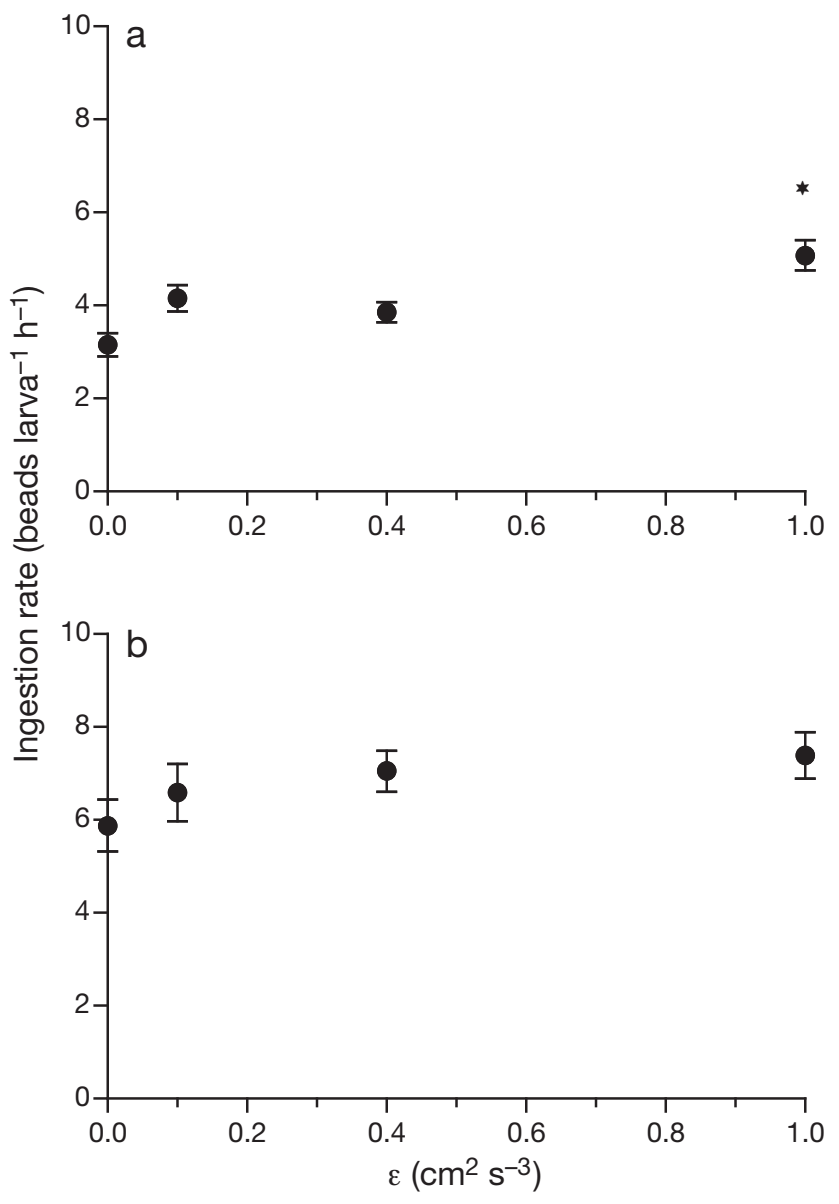

Fig. 2. Lytechinus pictus. Effect of flow (where $\varepsilon$ represents the turbulence level) on ingestion of flavored glass beads by early 4 -armed stage larvae. Symbols represent mean $\pm \mathrm{SE}$ of observed ingestion rates. (a) Bead concentration of $300 \mathrm{ml}^{-1}$, equivalent to a limiting prey concentration. Asterisk for the $1 \mathrm{~cm}^{2} \mathrm{~s}^{-3}$ treatment represents a significant difference of observed ingestion rate from that at other flow levels based on Tukey post hoc comparisons. (b) Bead concentration of $2500 \mathrm{ml}^{-1}$, equivalent to a satiating prey concentration

rate was $0.01 \pm 0.009 \mathrm{ml}$ larva $^{-1} \mathrm{~h}^{-1}(\mathrm{n}=327$; Fig. 2a) For the $1 \mathrm{~cm}^{2} \mathrm{~s}^{-3}$ flow treatment, the ingestion rate of 5.1 beads larva ${ }^{-1} \mathrm{~h}^{-1}$ and clearance rate of $0.02 \mathrm{ml}$ larva $^{-1} \mathrm{~h}^{-1}(\mathrm{n}=144)$ were significantly different (Tukey's test; $t_{220}=0.96 ; \mathrm{p}<0.001$ ) and $30 \%$ greater compared to the pooled average for the lower flow treatment results.

Lytechinus pictus larvae fed a concentration of 2500 beads $\mathrm{ml}^{-1}$, equivalent to a satiating prey concentration, showed a different pattern. Observed ingestion rate was not significantly different $\left(F_{3,530}=\right.$ $1.12 ; \mathrm{p}=0.34$ ) among flow treatments, with a pooled average ingestion rate of $6.7 \pm 5.9$ beads larva ${ }^{-1} \mathrm{~h}^{-1}$ and clearance rate of $0.02 \pm 0.02 \mathrm{ml} \mathrm{larva}^{-1} \mathrm{~h}^{-1}$ (n = 533; Fig. 2b). 
In Strongylocentrotus purpuratus larvae fed a concentration of 300 beads $\mathrm{ml}^{-1}$, equivalent to a limiting prey concentration, there was no significant difference $\left(F_{3,217}=1.714 ; \mathrm{p}=0.16\right)$ among flow treatments (Fig. 3). The pooled ingestion rate was $4.3 \pm 3.3$ beads larva ${ }^{-1} \mathrm{~h}^{-1}$ and clearance rate was $0.014 \pm 0.01 \mathrm{ml}$ $\operatorname{larva}^{-1} \mathrm{~h}^{-1}(\mathrm{n}=220)$. The ingestion rate was not significantly different from the pooled ingestion rate for Lytechinus pictus $(\mathrm{df}=6 ; t=0.5 ; \mathrm{p}=0.64)$.

\section{Long-term growth experiments}

Net population growth of the prey Rhodomonas lens was similar for the tested $\varepsilon$ levels $\left(F_{3,12}=0.138\right.$, $\mathrm{p}=0.94$ ). Mean growth rates of $R$. lens between 4 and $8 \mathrm{~d}$ were $0.125 \mathrm{~d}^{-1}$ in the $0 \mathrm{~cm}^{2} \mathrm{~s}^{-3}$ (still control), $0.244 \mathrm{~d}^{-1}$ in the $0.1 \mathrm{~cm}^{2} \mathrm{~s}^{-3}, 0.187 \mathrm{~d}^{-1}$ in the $0.4 \mathrm{~cm}^{2} \mathrm{~s}^{-3}$, and $0.182 \mathrm{~d}^{-1}$ in the $1 \mathrm{~cm}^{2} \mathrm{~s}^{-3}$ flow treatments. These growth rates were used to calculate ingestion and clearance rates in the $4 \mathrm{~d}$ grazing experiments using the equations of Frost (1972).

There was no significant difference $\left(F_{3,19}=0.704\right.$; $\mathrm{p}=0.56$ ) among flow treatments (Fig. 4) for grazing of food-limited Lytechinus pictus larvae on Rhodomonas lens prey over Days 4 to 8 . Mean ingestion rate was $13.0 \pm 8.9$ cells larva ${ }^{-1} \mathrm{~h}^{-1}$ in the $0 \mathrm{~cm}^{2} \mathrm{~s}^{-3}$ (still control), $23.2 \pm 19.4$ cells larva ${ }^{-1} \mathrm{~h}^{-1}$ in the $0.1 \mathrm{~cm}^{2} \mathrm{~s}^{-3}$ treatment, $17.0 \pm 9.2$ cells larva ${ }^{-1} \mathrm{~h}^{-1}$ in the $0.4 \mathrm{~cm}^{2} \mathrm{~s}^{-3}$ treatment, and $15.5 \pm 5.7$ cells larva ${ }^{-1} \mathrm{~h}^{-1}$ in the $1 \mathrm{~cm}^{2}$ $\mathrm{s}^{-3}$ flow treatment. The pooled ingestion rate was $16.8 \pm 10.6$ cells larva ${ }^{-1} \mathrm{~h}^{-1}$. There was also no significant difference $\left(F_{3,75}=1.636 ; \mathrm{p}=0.19\right)$ in growth with

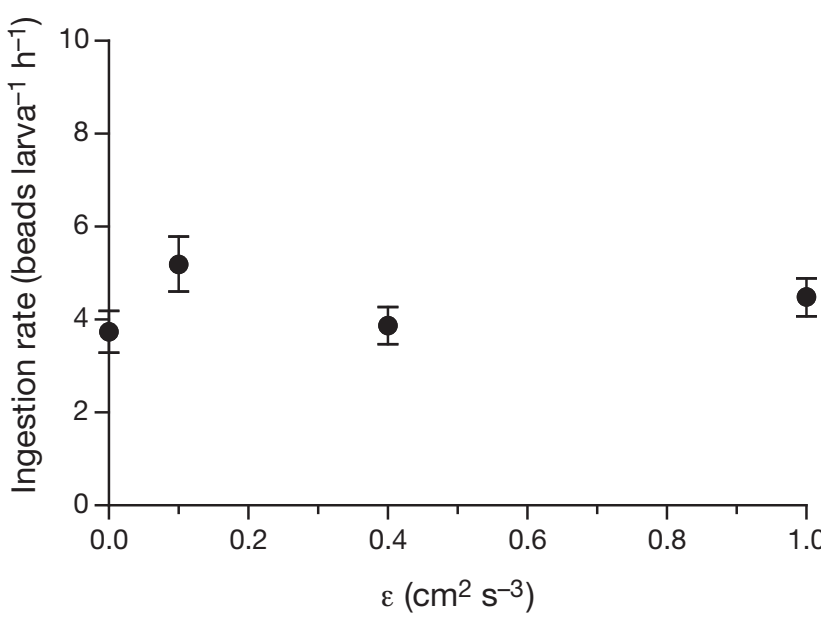

Fig. 3. Strongylocentrotus purpuratus. Effect of flow (where $\varepsilon$ represents the turbulence level) on ingestion of flavored glass beads by early 4 -armed stage larvae at a concentration of 300 beads $\mathrm{ml}^{-1}$, equivalent to a limiting prey concentration. Symbols represent mean \pm SE of observed ingestion rates

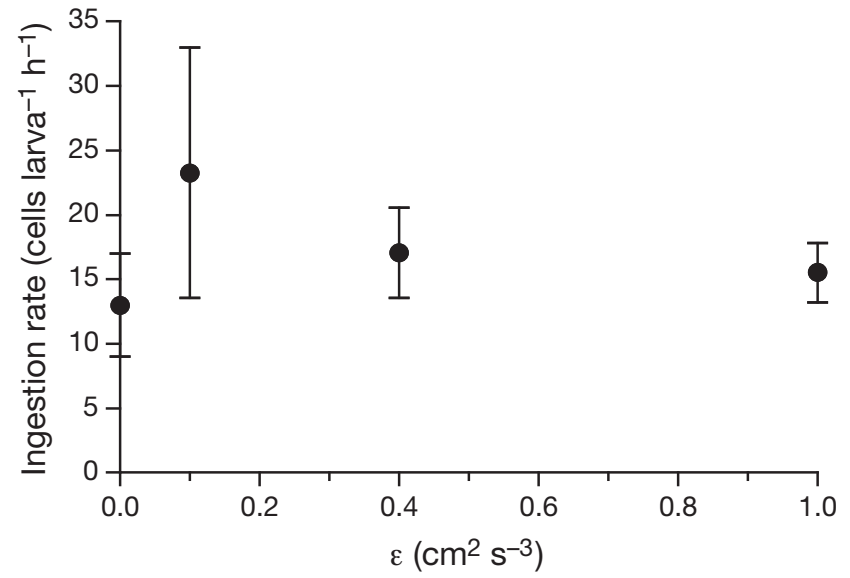

Fig. 4. Lytechinus pictus. Effect of flow (where $\varepsilon$ represents the turbulence level) on ingestion of the alga Rhodomonas lens by 4 -armed stage larvae at a limiting concentration of 300 cells ml ${ }^{-1}$ over Days 4 to 8 . Symbols represent mean $\pm \mathrm{SE}$

flow treatment. On Day 4 at the beginning of the experiment, mean $\mathrm{PO}$ arm length of $L$. pictus was $390.5 \pm 9.1 \mu \mathrm{m}$ in the $0 \mathrm{~cm}^{2} \mathrm{~s}^{-3}$ (still control) treatment, $375.4 \pm 7.8 \mu \mathrm{m}$ in the $0.1 \mathrm{~cm}^{2} \mathrm{~s}^{-3}$ treatment, $371.1 \pm$ $7.3 \mu \mathrm{m}$ in the $0.4 \mathrm{~cm}^{2} \mathrm{~s}^{-3}$ treatment, and $395.6 \pm$ $14.9 \mu \mathrm{m}$ in the $1 \mathrm{~cm}^{2} \mathrm{~s}^{-3}$ flow treatment. Pooled PO arm length on Day 4 was $383.2 \pm 9.8 \mu \mathrm{m}(\mathrm{n}=95)$. On Day 8, mean PO arm length was $465.6 \pm 19.3 \mu \mathrm{m}$ in the $0 \mathrm{~cm}^{2} \mathrm{~s}^{-3}$ (still control) treatment, $437 \pm 18.4 \mu \mathrm{m}$ in the $0.1 \mathrm{~cm}^{2} \mathrm{~s}^{-3}$ treatment, $487.6 \pm 14.8 \mu \mathrm{m}$ in the $0.4 \mathrm{~cm}^{2} \mathrm{~s}^{-3}$ treatment, and $465 \pm 15.9 \mu \mathrm{m}$ in the $1 \mathrm{~cm}^{2} \mathrm{~s}^{-3}$ flow treatment. Pooled postoral arm length on Day 8 was $461.6 \pm 21.4 \mu \mathrm{m}(\mathrm{n}=79)$. There was no significant difference $\left(F_{3,14}=0.820 ; \mathrm{p}=0.51\right)$ in developmental stage with flow treatment. On Day 8, $87 \%$ of the larvae were at the early 4 -armed stage in the $0 \mathrm{~cm}^{2} \mathrm{~s}^{-3}$ (still control) treatment, $100 \%$ in the $0.1 \mathrm{~cm}^{2} \mathrm{~s}^{-3}$ treatment, $100 \%$ in the $0.4 \mathrm{~cm}^{2} \mathrm{~s}^{-3}$ treatment, and $90 \%$ in the $1 \mathrm{~cm}^{2} \mathrm{~s}^{-3}$ flow treatment. These results confirm that a concentration of 300 cells ml ${ }^{-1}$ of $R$. lens was limiting, because in preliminary tests, $80 \%$ of the larvae reached the 6 -armed stage after $8 \mathrm{~d}$ when fed a satiating concentration of 5000 cells ml- ${ }^{-1}$ of $R$. lens.

Long-term flow exposure caused high mortality in Strongylocentrotus purpuratus larvae. The concentration of $S$. purpuratus larvae surviving after $8 \mathrm{~d}$ was significantly different $\left(F_{3,10}=7.034 ; \mathrm{p}=0.007\right)$ in the flow treatments compared to the still control. Mortality was $19 \%$ for the $0.1 \mathrm{~cm}^{2} \mathrm{~s}^{-3}, 22 \%$ for the $0.4 \mathrm{~cm}^{2}$ $\mathrm{s}^{-3}$, and $53 \%$ for the $1 \mathrm{~cm}^{2} \mathrm{~s}^{-3}$ flow treatments compared to $5 \%$ for the still control. As extensive initial tests showed that feeding was strongly density dependent (data not shown), it was not possible to obtain reliable ingestion rates for this species. 


\section{DISCUSSION}

\section{Comparisons to model predictions}

Encounter theory predictions of $\varepsilon_{\mathrm{cr}}$ based on swimming speed were lower than when suspension feeding was taken into account. Encounter model predictions of $\varepsilon_{\mathrm{cr}}$ based on swimming speed were $0.11 \mathrm{~cm}^{2}$ $\mathrm{s}^{-3}$ for Lytechinus pictus and $0.07 \mathrm{~cm}^{2} \mathrm{~s}^{-3}$ for Strongylocentrotus purpuratus. Even though urchin larvae are slow swimmers, they are also suspension feeders. When feeding current speed was incorporated, $\varepsilon_{\text {cr }}$ was much higher, ranging from $0.7 \mathrm{~cm}^{2} \mathrm{~s}^{-3}$ in L. pictus to $1.7 \mathrm{~cm}^{2} \mathrm{~s}^{-3}$ in $S$. purpuratus. As a result, turbulence would not be predicted to dominate over feeding behavior unless higher levels of turbulence were present.

The results of short-term grazing experiments were consistent with encounter model predictions based on suspension feeding. For Lytechinus pictus larvae, flow levels with $\varepsilon<1 \mathrm{~cm}^{2} \mathrm{~s}^{-3}$ had no net negative or positive effect on observed ingestion or growth. However, in short-term feeding experiments, ingestion rates were $30 \%$ greater in foodlimited larvae exposed to flow with $\varepsilon=1 \mathrm{~cm}^{2} \mathrm{~s}^{-3}$. For Strongylocentrotus purpuratus larvae, short-term exposure to any of the tested flow conditions did not significantly affect ingestion, which is also consistent with model predictions of $\varepsilon_{\mathrm{cr}}$ based on suspension feeding. Long-term exposure caused mortality, suggesting greater sensitivity of $S$. purpuratus larvae to turbulence compared to L. pictus larvae. Overall, these results are consistent with encounter model predictions based on feeding current speed and suggest that $\varepsilon_{\text {cr }}$ is high for suspension-feeding urchin larvae. The increase in ingestion for flows with $\varepsilon>\varepsilon_{\text {cr }}$ occurred only for food-limited, not satiated, L. pictus larvae; at satiating prey concentrations, turbulence does not enhance ingestion, despite higher encounters, due to limited room in the gut (Frost 1972).

Echinoderm pluteus larvae are thought to inhabit shallow depths based on their tendency to congregate near the surface in laboratory conditions (Sameoto \& Metaxas 2008, Sameoto et al. 2010). The highest levels of turbulence, outside of the surf zone or narrow surge channels, occur in near-surface waters of the coastal zone of the ocean that experience physical forcing from wind and surface waves, with an $\varepsilon$ of $10^{-3}$ to $1 \mathrm{~cm}^{2} \mathrm{~s}^{-3}$ (Soloviev et al. 1988, Gargett 1989, Thomas \& Gibson 1990, Granata \& Dickey 1991, MacKenzie \& Leggett 1991, 1993, Jiménez 1997). The $\varepsilon_{\text {cr }}$ of 0.7 to $1.7 \mathrm{~cm}^{2} \mathrm{~s}^{-3}$ for the urchin larvae studied represent the highest values of turbulence present in the ocean; it is unlikely that larvae will experience turbulence levels $>\varepsilon_{\mathrm{cr}}$ under natural conditions. Thus, model and experimental results suggest that levels of turbulence present in the ocean are insufficient to increase ingestion by urchin larvae.

The greatest increase in clearance rates is predicted for nonmotile and slow-swimming organisms exposed to low levels of turbulence typically present in the coastal zone of the ocean (Rothschild \& Osborn 1988, Kiørboe \& Saiz 1995). In the nonmotile helioflagellate Ciliophrys marina, clearance rates increase 3 -fold when exposed to a turbulence level of $0.1 \mathrm{~cm}^{2}$ $\mathrm{s}^{-3}$, which is greater than $\varepsilon_{\mathrm{cr}}=0.004 \mathrm{~cm}^{2} \mathrm{~s}^{-3}$, compared to the still control (Shimeta et al. 1995). Urchin larvae are slow swimmers, which would suggest that their grazing rate would increase due to turbulence dominating their swimming behavior. Lytechinus pictus larvae have swimming speeds of $0.4 \mathrm{~mm} \mathrm{~s}^{-1}$ and Strongylocentrotus purpuratus have swimming speeds of $0.2 \mathrm{~mm} \mathrm{~s}^{-1}$ (Maldonado 2009). However, they are also suspension feeders that can sense and capture individual particles (Strathmann 2007). In this study, $\varepsilon_{\mathrm{cr}}$ based on suspension-feeding behavior was equivalent to the highest turbulence levels found in the coastal zone of the ocean. Short-term exposure to turbulence levels $<\varepsilon_{\text {cr }}$ had no effect on clearance and ingestion rates in L. pictus and S. purpuratus larvae. Similarly, the copepod Acartia tonsa feeding in suspension mode experiences no significant increase in ingestion when exposed to turbulence with $\varepsilon>10^{-3} \mathrm{~cm}^{2} \mathrm{~s}^{-3}$, the $\varepsilon_{\mathrm{cr}}$ when ambush feeding, because the velocity difference generated relative to turbulence is large (Saiz \& Kiørboe 1995). Thus, results from this study are consistent with previous work in which suspension feeders and fastswimming predators are not predicted to benefit from low levels of turbulence (Kiørboe \& Saiz 1995).

Turbulence levels above an optimal level can result in decreased ingestion rate due to post-encounter processes (MacKenzie et al. 1994). For example, ingestion rates are lower in the copepod Acartia tonsa feeding in suspension mode exposed to a turbulence treatment with dissipation rate of $\varepsilon=10 \mathrm{~cm}^{2} \mathrm{~s}^{-3} \mathrm{com}$ pared to the still control (Saiz \& Kiørboe 1995, Kiørboe 1997). After a prey particle is encountered, it can be advected out of the predator's perceptive radius before it can be ingested because the local turbulent velocity fluctuation is greater than the predator reaction speed (MacKenzie et al. 1994, Kiørboe \& Saiz 1995, MacKenzie \& Kiørboe 2000). However, in short-term experiments in the present study, ingestion rates were not lower in Lytechinus pictus and Strongylocentrotus purpuratus larvae exposed to 
flow with $\varepsilon<1 \mathrm{~cm}^{2} \mathrm{~s}^{-3}$ compared to the still control. Unlike copepods, which detect prey using relatively long antennae, urchin larvae first detect particles at the tips of their $20 \mu \mathrm{m}$ long cilia and then move the particles towards their mouth using reversal of ciliary beat (Strathmann 1971, 2007). At the scale of the cilia, the local turbulence-induced velocity may be sufficiently low that larvae can react to the prey. As a result, on short time scales, turbulence equivalent to the highest levels found in the coastal zone of the ocean may not negatively affect post-encounter processes because urchin larvae feed on very small scales.

\section{Species comparisons}

Flow sensitivity was species specific. Early 4armed stage Strongylocentrotus purpuratus larvae were more sensitive to long-term flow exposure than Lytechinus pictus larvae. While there was low mortality in L. pictus larvae for an $8 \mathrm{~d}$ exposure at all flow conditions, there was no significant increase in ingestion at the highest flow level as observed in the short-term experiments. This could be due to sublethal effects on grazing from long-term exposure to high flow conditions. Larvae may reject more particles or spend less time feeding, resulting in lower ingestion despite predicted increases in encounter rates, when exposed to turbulence levels $>\varepsilon_{\mathrm{cr}}$ for long periods of time. In other zooplankton, feeding under high levels of turbulence requires more energy compared to lower levels of turbulence (Alcaraz et al. 1994). Thus, ingestion rates would reach a maximal level without causing mortality. However, further work is needed to determine the mechanism. Longterm exposure to turbulence caused high mortality in $S$. purpuratus larvae despite the similarity in shortterm grazing rates with $L$. pictus. Species differences in mortality were most likely due to physiological differences rather than the experimental chamber. Larval size was $<20 \%$ of the gap width of $3.5 \mathrm{~mm}$ based on a total length of $600 \mu \mathrm{m}$ for $L$. pictus larvae and $400 \mu \mathrm{m}$ for $S$. purpuratus larvae. If differences were caused by wall effects due to the size of the Couette flow chamber, greater mortality would be expected in L. pictus larvae compared to $S$. purpuratus larvae because they are larger in size with longer postoral arms, but the opposite was true. Because $S$. purpuratus larvae have smaller ciliary bands than L. pictus larvae, L. pictus larvae may have a lower specific clearance rate, or clearance rate per unit length of ciliated band (Hart 1996), compared to S. purpuratus larvae. Echinoderm larvae with low specific clearance rates have higher metabolic efficiencies because they metamorphose earlier compared to species with high specific clearance rates (Hart 1996). Higher metabolic efficiency could be an explanation for the greater survival of L. pictus larvae exposed to flow compared to $S$. purpuratus larvae, but further work on physiological features such as clearance and metabolic rates in larvae exposed to flow is needed.

Urchin larvae demonstrate preferences for size and flavor of prey when suspension feeding in still water (Table 2; Rassoulzadegan et al. 1984, Appelmans 1994, Pedrotti 1995). This suggests that larvae selectively filter particles out of a dilute suspension in the ocean, which is important for modeling plankton population dynamics and the ocean carbon cycle

Table 2. Summary of clearance rates of echinoderm pluteus larvae in still water. Clearance rate values are means \pm SD. PO: postoral; na: not available

\begin{tabular}{|c|c|c|c|c|c|c|c|c|c|}
\hline \multirow[t]{2}{*}{ Species } & \multirow{2}{*}{$\begin{array}{c}\text { PO arm } \\
\text { length } \\
(\mu \mathrm{m})\end{array}$} & \multirow[t]{2}{*}{$\begin{array}{l}\text { Developmental } \\
\text { stage }\end{array}$} & \multirow[t]{2}{*}{$\begin{array}{l}\text { Temp. } \\
\left({ }^{\circ} \mathrm{C}\right)\end{array}$} & \multirow[t]{2}{*}{$\begin{array}{l}\text { Species or } \\
\text { bead 'flavor' }\end{array}$} & \multirow[t]{2}{*}{$\begin{array}{c}\text { Concentration } \\
\left(\mathrm{ml}^{-1}\right)\end{array}$} & \multirow{2}{*}{$\begin{array}{c}\text { Bead } \\
\text { diameter } \\
(\mu \mathrm{m})\end{array}$} & \multicolumn{2}{|c|}{$\begin{array}{l}\text { Clearance rate } \\
\left(\mathrm{ml} \mathrm{larva}{ }^{-1} \mathrm{~h}^{-1}\right)\end{array}$} & \multirow[t]{2}{*}{ Source } \\
\hline & & & & & & & Beads & Live cells & \\
\hline $\begin{array}{l}\text { Dendraster } \\
\text { excentricus }\end{array}$ & 500 & Late 4 -arm & 22 & $\begin{array}{l}\text { Dunaiella } \\
\text { tertiolecta }\end{array}$ & 2000 & 20.0 & 0.05 & na & $\begin{array}{c}\text { Appelmans } \\
\text { (1994) }\end{array}$ \\
\hline \multirow[t]{2}{*}{$\begin{array}{l}\text { Paracentrotus } \\
\text { lividus }\end{array}$} & 557 & Early 4-arm & 20 & $\begin{array}{l}\text { Crichosphaera } \\
\text { elongata }\end{array}$ & 300 & 18.5 & $0.18 \pm 0.09$ & na & $\begin{array}{c}\text { Pedrotti } \\
\text { (1995) }\end{array}$ \\
\hline & 810 & 6-arm & 20 & C. elongata & 1500 & 18.5 & $0.53 \pm 0.15$ & na & \\
\hline Arbacia & 338 & Early 4-arm & 20 & C. elongata & 300 & 18.5 & $0.09 \pm 0.06$ & $0.01 \pm 0.06$ & Pedrotti \\
\hline lixula & 569 & 6-arm & 20 & C. elongata & 1500 & 18.5 & $0.22 \pm 0.10$ & $0.02 \pm 0.01$ & (1995) \\
\hline $\begin{array}{l}\text { Strongylocentrotus } \\
\text { purpuratus }\end{array}$ & NA & Early 4-arm & $9-14$ & Unflavored & $\begin{array}{c}1000- \\
2400\end{array}$ & 20 & 0.06 & na & Hart (1996) \\
\hline $\begin{array}{l}\text { Lytechinus } \\
\text { pictus }\end{array}$ & 380 & 4-arm & 20 & D. tertiolecta & $\begin{array}{l}300 \\
2500\end{array}$ & $\begin{array}{l}20.0 \\
20.0\end{array}$ & $\begin{array}{l}0.01 \pm 0.01 \\
0.02 \pm 0.02\end{array}$ & $\begin{array}{c}0.04 \\
\text { na }\end{array}$ & This study \\
\hline $\begin{array}{l}\text { Strongylocentrotus } \\
\text { purpuratus }\end{array}$ & 180 & Late prism & 16 & $\begin{array}{l}\text { Rhodomonas } \\
\text { lens }\end{array}$ & 300 & 20.0 & $0.01 \pm 0.01$ & na & This study \\
\hline
\end{tabular}


(Appelmans 1994). Clearance rates measured in the still controls in this study are consistent with previous observations because Lytechinus pictus and Strongylocentrotus purpuratus larvae preferentially ingested particles of $20 \mu \mathrm{m}$ diameter, ingested more particles that were 'flavored' (i.e. incubated with algal exudate) compared to 'unflavored' (i.e. particles soaked in FSW), and clearance rates depended on concentration of prey. Any differences in clearance rates between this and previous studies (Table 2) are most likely due to differences in experimental conditions. For example, greater ingestion rates in short-term experiments compared to longterm experiments were expected, as observed by Pedrotti (1995) (Table 2), because long-term experiments average feeding rates over time. However, lower ingestion rates were observed in short-term experiments compared to long-term experiments. We used 2 different species to flavor beads in the short-term experiments and to feed larvae in the long-term experiments, whereas Pedrotti (1995) used 1 species. The differences in grazing rates observed in this study could reflect preferences of larvae for live Rhodomonas lens cells compared to flavored glass beads. However, this prediction could not be tested because $R$. lens cells disintegrate immediately upon ingestion in short-term experiments. Another difference between our study and that of Pedrotti (1995) is that we measured ingestion rates after $4 \mathrm{~d}$, whereas she measured ingestion rates after 15 to $24 \mathrm{~h}$. We conducted extensive preliminary experiments in which ingestion rates were measured every $24 \mathrm{~h}$. Ingestion rates were lower and more variable after $24 \mathrm{~h}$, and we found that a $4 \mathrm{~d}$ period was the shortest that could resolve changes in prey concentrations given low ingestion rates of larvae and low larval concentrations. This is the first time that grazing rates have been calculated after this amount of time for sea urchin larvae, so it is difficult to predict results given differences in experiment duration and prey species.

\section{SUMMARY}

Overall, the contribution of our study is that we investigated suspension feeding in urchin larvae under conditions of fluid motion, which are more representative of ocean conditions than still conditions. Urchin larvae are representative of planktotrophic marine invertebrate larvae, most of which clear particles from suspension using a ciliary feeding current (Strathmann 1971). Additionally, marine invertebrate larvae are found throughout the water column (see Metaxas 2001 for review). Thus, most planktotrophic marine invertebrate larvae would not be expected to benefit from turbulence in the ocean.

The use of simple Couette flow is but 1 step towards investigating the effects of ocean turbulence on plankton. While simple Couette flow is fully characterized and all organisms experience similar conditions, it does not capture the unsteady nature of vorticity and turbulent intensity (Peters \& Marrasé 2000, Jumars et al. 2009). This deficiency can be addressed by conducting grazing studies using flow fields that better approximate the statistical properties of ocean turbulence, such as the T-box isotropic turbulence chamber (Webster et al. 2004, Yen et al. 2008). Additionally, imaging the instantaneous velocity of urchin larvae and their prey in isotropic turbulence using the T-box would allow direct measurement of the encounter rate between urchin larvae and their prey, to correlate the encounter rate with the velocity gradient at the same location.

The results of laboratory experiments suggest that turbulence in the ocean does not increase ingestion in suspension-feeding planktotrophic marine invertebrate larvae. Even though these larvae are slow swimmers, suspension feeding dominates and they do not experience turbulence-induced increases in ingestion as in other slow-swimming plankton. However, experimental approaches that more closely mimic ocean conditions are needed to determine the ecological relevance of turbulence effects on urchin larvae and other plankton.

Acknowledgements. We thank M. Brito, J. Calderón, and S. Garcia for technical assistance; M. Landry and B.G. Mitchell for use of their particle counters; and M. Hildebrand, G. Rouse, and B. Palenik for use of their microscopes. Thanks also to M. Ohman and P. Franks, whose comments greatly improved this manuscript. E.M. was supported by NSF fellowships from the Minority Access to Science, Engineering, and Math (MASEM) and the Graduate Research Fellowship Programs, and the Ford Foundation Diversity Dissertation Fellowship Program.

\section{LITERATURE CITED}

Alcaraz M, Saiz E, Cabet A (1994) Small-scale turbulence and zooplankton metabolism: effects of turbulence on heartbeat rates of planktonic crustaceans. Limnol Oceanogr 39:1465-1470

Appelmans N (1994) Sites of particle selection determined from observations of individual feeding larvae of the sand dollar Dendraster excentricus. Limnol Oceanogr 39: 404-411

Børsheim KY, Andersen S (1987) Grazing and food size selection by crustacean zooplankton compared to pro- 
duction of bacteria and phytoplankton in a shallow Norwegian mountain lake. J Plankton Res 9:367-379

> Cloern JE (1996) Phytoplankton bloom dynamics in coastal ecosystems: a review with some general lessons from sustained investigation of San Francisco Bay, California. Rev Geophys 34:127-168

Coles D (1965) Transition in circular Couette flow. J Fluid Mech 21:385-425

Denman KL, Powell TM (1984) Effects of physical processes on planktonic ecosystems in the coastal ocean. Oceanogr Mar Biol Annu Rev 22:125-168

Fenaux L, Cellario C, Rassoulzadegan F (1988) Sensitivity of different morphological stages of the larva of Paracentrotus lividus (Lamarck) to quantity and quality of food. In: Burke RD, Mladenov MV, Lambert P, Parsley RL (eds) Echinoderm biology. Balkema, Rotterdam, p 259-266

> Frost BW (1972) Effects of size and concentration of food particles on the feeding behavior of the marine planktonic copepod Calanus pacificus. Limnol Oceanogr 17: 805-815

Gargett AE (1989) Ocean turbulence. Annu Rev Fluid Mech 21:419-451

> George SB, Lawrence JM, Lawrence AL (2004) Complete larval development of the sea urchin Lytechinus variegatus fed an artificial feed. Aquaculture 242:217-228

Granata TC, Dickey TD (1991) The fluid mechanics of copepod feeding in a turbulent flow: a theoretical approach. Prog Oceanogr 26:243-261

Hall JA, Barrett DP, James MR (1993) The importance of phytoflagellate, heterotrophic flagellate and ciliate grazing on bacteria and picophytoplankton sized prey in a coastal marine environment. J Plankton Res 15:1075-1108

Hansen B, Bjornsen PK, Hansen PJ (1994) The size ratio between planktonic predators and their prey. Limnol Oceanogr 39:395-403

Hart MW (1996) Variation in suspension feeding rates among larvae of some temperate, eastern Pacific echinoderms. Invertebr Biol 115:30-45

Hart MW, Strathmann RR (1994) Functional consequences of phenotypic plasticity in echinoid larvae. Biol Bull (Woods Hole) 186:291-299

Holling CS (1961) Principles of insect predation. Annu Rev Entomol 6:163-182

Jarrett JN (2003) Seasonal variation in larval condition and postsettlement performance of the barnacle Semibalanus balanoides. Ecology 84:384-390

Jiménez J (1997) Oceanic turbulence at millimeter scales. Sci Mar 61(Suppl 1):47-56

Juhl AR, Latz MI (2002) Mechanism of fluid shear-induced inhibition of population growth in a red-tide dinoflagellate. J Phycol 38:683-694

Juhl AR, Velasquez V, Latz MI (2000) Effect of growth conditions on flow-induced inhibition of population growth of a red-tide dinoflagellate. Limnol Oceanogr 45: 905-915

> Juhl AR, Trainer VL, Latz MI (2001) Effect of fluid shear and irradiance on population growth and cellular toxin content of the dinoflagellate Alexandrium fundyense. Limnol Oceanogr 46:758-764

> Jumars PA, Trowbridge JH, Boss E, Karp-Boss L (2009) Turbulence-plankton interactions: a new cartoon. PSZN I: Mar Ecol 30:133-150

Kelly MS, Hunter AJ, Scholfield CL, McKenzie JD (2000) Morphology and survivorship of larval Psammechinus miliaris (Gmelin) (Echinodermata: Echinoidea) in response to varying food quantity and quality. Aquaculture 183:223-240

Kiørboe T (1997) Small-scale turbulence, marine snow formation, and planktivorous feeding. Sci Mar 61(Suppl 1): $141-158$

Kiørboe T, Saiz E (1995) Planktivorous feeding in calm and turbulent environments, with emphasis on copepods. Mar Ecol Prog Ser 122:135-145

Lamare MD, Barker MF (1999) In situ estimates of larval development and mortality in the New Zealand sea urchin Evechinus chloroticus (Echinodermata: Echinoidea). Mar Ecol Prog Ser 180:197-211

Latz MI, Case JF, Gran RL (1994) Excitation of bioluminescence by laminar fluid shear associated with simple Couette flow. Limnol Oceanogr 39:1424-1439

Latz MI, Allen J, Sarkar S, Rohr J (2009) Effect of fully characterized unsteady flow on population growth of the dinoflagellate Lingulodinium polyedrum. Limnol Oceanogr 54: 1243-1256

> Lazier JRN, Mann KH (1989) Turbulence and the diffusive layers around small organisms. Deep-Sea Res 36: 1721-1733

- MacKenzie BR, Kiørboe T (1995) Encounter rates and swimming behavior of pause-travel and cruise larval fish predators in calm and turbulent laboratory environments. Limnol Oceanogr 40:1278-1289

MacKenzie BR, Kiørboe T (2000) Larval fish feeding and turbulence: a case for the downside. Limnol Oceanogr 45:1-10

> MacKenzie BR, Leggett WC (1991) Quantifying the contribution of small-scale turbulence to the encounter rates between larval fish and their zooplankton prey: effects of wind and tide. Mar Ecol Prog Ser 73:149-160

MacKenzie BR, Leggett WC (1993) Wind-based models for estimating the dissipation rates of turbulent energy in aquatic environments: empirical comparisons. Mar Ecol Prog Ser 94:207-216

> MacKenzie BR, Miller TJ, Cyr S, Leggett WC (1994) Evidence for a dome-shaped relationship between turbulence and larval fish ingestion rates. Limnol Oceanogr 39:1790-1799

Maldonado EM (2009) Biological-physical interactions in marine plankton: the effects of small-scale turbulence on grazing, growth, and swimming of sea urchin larvae. $\mathrm{PhD}$ dissertation, Scripps Institution of Oceanography, University of California, San Diego, CA

Maldonado EM, Latz MI (2007) Shear-stress dependence of dinoflagellate bioluminescence. Biol Bull (Woods Hole) 212:242-249

Metaxas A (2001) Behaviour in flow: perspectives on the distribution and dispersion of meroplanktonic larvae in the water column. Can J Fish Aquat Sci 58:86-98

> Meyer E, Green AJ, Moore M, Manahan DT (2007) Food availability and physiological state of sea urchin larvae (Strongylocentrotus purpuratus). Mar Biol 152: 179-191

Paulay G, Boring L, Strathmann RR (1985) Food limited growth and development of larvae: experiments with natural seawater. J Exp Mar Biol Ecol 93:1-10

Pedrotti ML (1995) Food selection (size and flavor) during development of echinoderm larvae. Invertebr Reprod Dev 27:29-39

Peters F, Marrasé C (2000) Effects of turbulence on plankton: an overview of experimental evidence and some theoretical considerations. Mar Ecol Prog Ser 205:291-306 
Pineda J, Hare JA, Sponaugle S (2007) Larval transport and dispersal in the coastal ocean and consequences for population connectivity. Oceanography 20:22-39

Podolsky RD (1994) Temperature and water viscosity: physiological versus mechanical effects on suspension feeding. Science 265:100-103

Rassoulzadegan F, Fenaux L, Strathmann RR (1984) Effect of flavor and size on selection of food by suspension-feeding plutei. Limnol Oceanogr 29:357-361

Riffell JA, Zimmer RK (2007) Sex and flow: the consequences of fluid shear for sperm-egg interactions. J Exp Biol 210:3644-3660

Riisgard HU, Larsen PS (2010) Particle capture mechanisms in suspension-feeding invertebrates. Mar Ecol Prog Ser 418:255-293

Rothschild BJ (1986) Dynamics of marine fish populations. Harvard University Press, Cambridge, MA

Rothschild BJ, Osborn TR (1988) Small-scale turbulence and plankton contact rates. J Plankton Res 10:465-474

Saiz E, Kiørboe T (1995) Predatory and suspension feeding of the copepod Acartia tonsa in turbulent environments. Mar Ecol Prog Ser 122:147-158

Sameoto JA, Metaxas A (2008) Interactive effects of haloclines and food patches on the vertical distribution of 3 species of temperate invertebrate larvae. J Exp Mar Biol Ecol 367:131-141

Sameoto JA, Ross T, Metaxas A (2010) The effect of flow on larval vertical distribution of the sea urchin, Strongylocentrotus droebachiensis. J Exp Mar Biol Ecol 383: 156-163

Schiopu D, George SB, Castell J (2006) Ingestion rates and dietary lipids affect growth and fatty acid composition of Dendraster excentricus larvae. J Exp Mar Biol Ecol 328: 47-75

Schlichting H (1979) Boundary-layer theory. McGraw-Hill, Thornwood, NY

Sewell MA, Cameron MJ, McArdle BJ (2004) Developmental plasticity in larval development in the echinometrid sea urchin Evechinus chloroticus with varying food ration. J Exp Mar Biol Ecol 309:219-237

Shimeta J (2009) Influence of flow speed on the functional

Editorial responsibility: Matthias Seaman,

Oldendorf/Luhe, Germany response of a passive suspension feeder, the spionid polychaete Polydora cornuta. Mar Biol 156:2451-2460

Shimeta JA, Jumars PA, Lessard EJ (1995) Influences of turbulence on suspension feeding by planktonic protozoa; experiments in laminar shear fields. Limnol Oceanogr 40:845-859

> Six KD, Maier-Reimer E (1996) Effects of plankton dynamics on seasonal carbon fluxes in an ocean general circulation model. Global Biogeochem Cycles 10:559-583

Soloviev AV, Vershinsky NV, Bezverchnii VA (1988) Smallscale turbulence measurements in the thin surface layer of the ocean. Deep-Sea Res 35:1859-1874

Sterner RW, Elser JJ, Hessen DO (1992) Stoichiometric relationships among producers, consumers and nutrient cycling in pelagic ecosystems. Biogeochemistry 17: 49-67

> Strathmann RR (1971) The feeding behavior of planktotrophic echinoderm larvae: mechanisms, regulation, and rates of suspension-feeding. J Exp Mar Biol Ecol 6: $109-160$

Strathmann RR (1975) Larval feeding in echinoderms. Am Zool 15:717-730

Strathmann RR (2007) Time and extent of ciliary response to particles in a non-filtering feeding mechanism. Biol Bull (Woods Hole) 212:93-103

Strathmann RR, Fenaux L, Strathmann MF (1992) Heterochronic developmental plasticity in larval sea urchins and its implications for evolution of nonfeeding larvae. Evolution 46:972-986

Tett P, Edwards A (1984) Mixing and plankton: an interdisciplinary theme in oceanography. Oceanogr Mar Biol Annu Rev 22:99-123

> Thomas WH, Gibson CH (1990) Quantified small-scale turbulence inhibits a red tide dinoflagellate, Gonyaulax polyedra Stein. Deep-Sea Res 37:1583-1593

Webster DR, Brathwaite A, Yen J (2004) A novel turbulence apparatus for simulating oceanic isotropic turbulence at low Reynolds number. Limnol Oceanogr Methods 2:1-12

Yen J, Rasberry KD, Webster DR (2008) Quantifying copepod kinematics in a laboratory turbulence apparatus. J Mar Syst 69:283-294

Submitted: September 27, 2010; Accepted: June 8, 2011 Proofs received from author(s): August 15, 2011 